\title{
Identification and Characterization of a Cellulase from Bacterial of Indigenous of Rice Bran
}

\author{
$\underline{\text { Akyunul Jannah }}^{1,2}$, Aulani $^{\prime}$ am $^{3}$, Tri Ardyati ${ }^{4}$, Suharjono $^{4}$, \\ ${ }^{1}$ Doctoral program of Biology Department, Brawijaya University, Malang, Indonesia \\ ${ }^{2}$ Chemistry Department of Islamic State Maulana Malik Ibrahim University, Malang, Indonesia \\ ${ }^{3}$ Chemistry Department, Brawijaya University, Malang, Indonesia \\ ${ }^{4}$ Biology Department, Brawijaya University, Malang, Indonesia \\ Email : akyunul_jannah2008@yahoo.com
}

\begin{abstract}
Cellulolytic bacteria have been isolated from rice mill waste (rice bran) that isolates BE 8 and BE 14. Cellulolytic bacteria is a producer of cellulase enzymes involved in the degradation of cellulose waste, textiles, detergents, glucose industrial etc. The purpose of this study was to molecular identification of cellulolytic bacterial isolates from indigenous rice bran using $16 \mathrm{~S}$ rRNA and characterization of cellulase enzymes produced. The results showed that the BE 8 isolate is Bacillus subtilis with a similarity of $100 \%$ of Bacillus subtilis ZJ2. While BE14 isolates is Bacillus cereus with a similarity of $99 \%$ of Bacillus cereus Se05. Cellulase enzymes produced $\mathrm{BE} 8$ and $\mathrm{BE} 14$ isolate have the highest activity at $\mathrm{pH} 6$ and a temperature of $60{ }^{\circ} \mathrm{C}$. On the influence of metal ions, isolate BE 8 has the highest activity with metal $\mathrm{Mg}^{2+}$, whereas $\mathrm{BE} 14$ isolate has the highest activity with their metal $\mathrm{Mn}^{2+}$.
\end{abstract}

Keyword : cellulolytic bacteria, rice bran, moleculeridentfication and cellulase enzyme.

\section{INTRODUCTION}

Cellulolytic bacteria as a producer of cellulase enzymes can be obtained from cellulose-rich biomass particularly from agricultural waste such as bagasse, rice bran, straw etc. Rice bran contains $27 \%$ cellulose (Baig et al., Nd), or 32.8\%, $14.9 \%$ protein; $12.5 \%$ fat and $2.1 \%$ ash (Ardiansyah, 2010). Chemical content of rice bran is a potential for the survival of microorganisms cellulolitic because of the high cellulose content and availability of complete supporting media such as proteins and minerals. Bajaj et al. (2009) have isolated a strain of Bacillus M-9 indigenusrice bran which decomposes and is capable of producing endoglucanase significantly in CYPE media $\left(1 \% \mathrm{CMC}, 0.5 \%\right.$ peptone, $0.5 \%$ yeast extract, $0.1 \% \mathrm{~K}_{2} \mathrm{HPO}_{4}, 0.02$ $\mathrm{MgSO}_{4}$ and $\left.0.5 \% \mathrm{NaCl}\right) \mathrm{pH} 9-10$. Nirmala \& Shindu (2011) have also been isolated Bacillus circulans of indigenus rice bran which decomposes and is capable of producing endoglucanase on CYPE media at $\mathrm{pH}$ 9-10. Cellulolytic bacteria isolation in the bran has been done as a producer of cellulase enzymes and proceeds with the process of molecular identification and characterization of cellulase enzyme activity. The identification of the molecular basis of bacterial isolates using the gene sequence 16rRNA cellulolitic because in this gene are more stable and are ubiquity in bacteria and appropriate for analysis at the molecular level (Singh, 2012) 


\section{EXPERIMENTAL}

\section{Molecular Identification of Cellulolytic Bacteria}

Molecularidentification of bacteria based on 16S rRNA gene sequences by PCR and compared with sequence data available in the Gene Bank. Several stages for identification of phylogenetic includes a) the isolation of chromosomal DNA using commercial kits, b) verification by agarose gel electrophoresis, c) amplification of DNA by PCR using primers 28f, $651 \mathrm{f}$ and 1495r, d) Purification products of 16S rRNAe) Sequencing and Analysis of gene 16s rRNA.

\section{Characterization of cellulase activity of cellulolytic bacteria}

pH. Substrate of 1\% CMC in $1800 \mathrm{~mL}$ of $50 \mathrm{mM}$ phosphate buffer (pH 6,7,8,9 and 10), $200 \mathrm{~mL}$ of crude extract cellulase enzyme were added and incubated at $50{ }^{\circ} \mathrm{C}$ for 60 minutes. Cellulase enzyme activity was analyzed using DNS method (Miller, 1959).

Temperature. Substrate of $1 \% \mathrm{CMC}$ in $1800 \mathrm{~mL}$ of $50 \mathrm{mM}$ phosphate buffer (pH optimum), $200 \mathrm{~mL}$ of crude extract cellulase enzyme were added and incubated at various temperature (20, $30,40,50$ and $60{ }^{\circ} \mathrm{C}$ ) for 60 minutes.

Various of subsrate concentration. 0,$5 ; 0,75 ; 1 ; 1,25$ and 1,5\% CMC in $1800 \mu \mathrm{L} 50 \mathrm{mM}$ buffer phosphateon optimum $\mathrm{pH}, 200 \mu \mathrm{L}$ of crude enzyme were added and incubation on optimum temperature for 60 minutes.

Cofactor (metal ions). Substrate of $1 \% \mathrm{CMC}$ dalam $1800 \mu \mathrm{L} 50 \mathrm{mM}$ buffer phosphate (optimumpH) with various of metals ions $\left(\mathrm{Co}^{2+}, \mathrm{Mn}^{2+}, \mathrm{Mg}^{2+}, \mathrm{Na}^{+}, \mathrm{K}^{+}\right.$dan $\left.\mathrm{Ca}^{2+}\right), 200 \mu \mathrm{L}$ crude enzyme cellulase and incubated on optimum temperature for 60 minutes.

\section{RESULT AND DISCUSSION}

Cellulolytic bacterial isolates from rice bran was selected and isolates BE 8 and BE 14 has the highest cellulase activity of 25 isolates obtained.

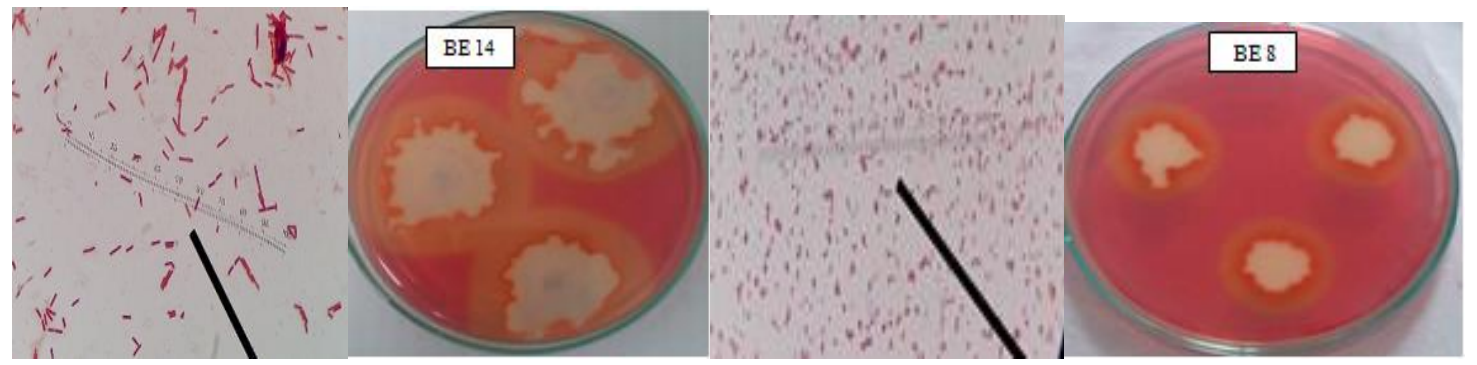

(a)

(b)

Figure 1. Morfology of colony of bacteria isolate using Gram staining andCongo red (a) isolate of BE 14 dan (b) isolate of BE 8.

Isolates BE 14 and BE 8 were a gram-positive bacterium with a rod shape. Based on staining with Congo red both have the ability to isolate cellulolytic marked by a clear zone around the colony indicating that cellulose substrate in 1\% CMC media hydrolyzed by cellulase enzymes 
released by the bacteria isolates into glucose. Cellulolytic capability can be seen from the value of the index celluloliticie ratio between the diameter and the diameter of the clear zone cells. Isolates $\mathrm{BE} 14$ has an index of 0.54 and cellulase enzyme activity of $1.31 \mathrm{U} / \mathrm{mL}$, whereas isolate BE 8 enzyme activity of 0.63 and $2.16 \mathrm{U} / \mathrm{mL}$.

Amplicon of bacterial isolates of amplification product using universal primers $28 \mathrm{f}$ (5`AGAGTTTGATCATGGCTCAG3`), 651f(5`AATTACTGGGCGTAAAG3`) and 1495r (5'TACGGCTACCTTGTTACCA3`) which resulted in a single band on the size of about 1500 bp. This size is nearly equal to the size of bacteria in NCBI.

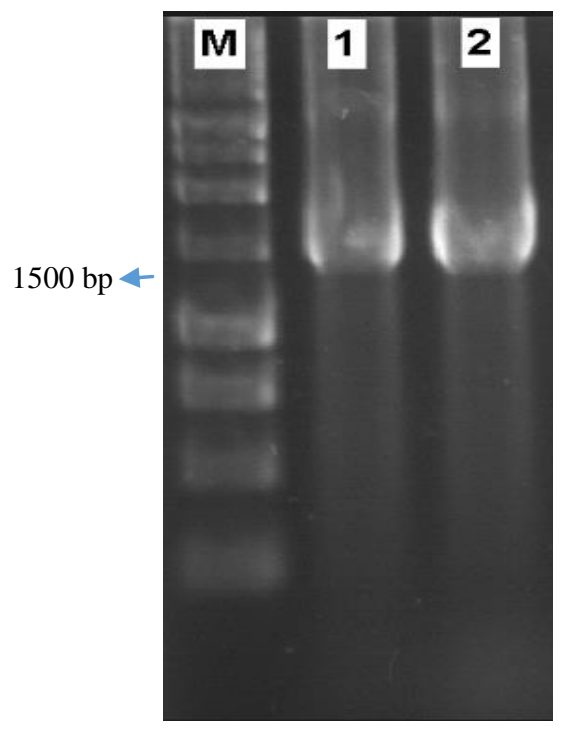

(a)

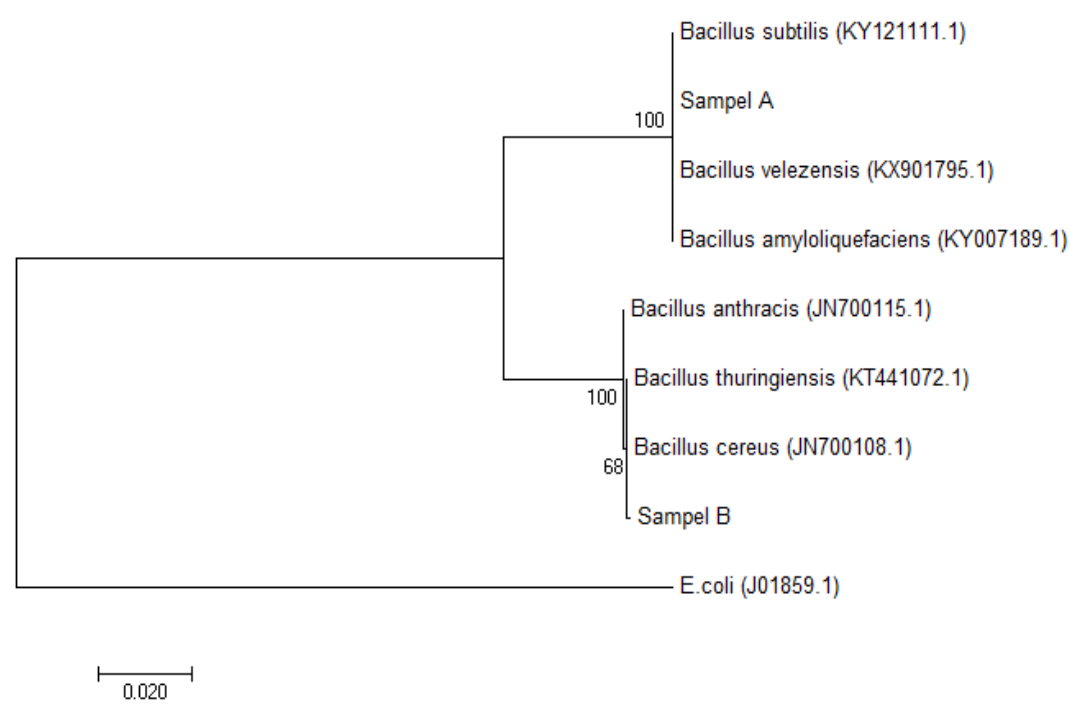

(b)

Figure 2. (a) DNA Amplicon of bacteria isolate using primer 28f, 651f and 1495r. 1 (isolate BE 14) and 2 (isolat BE 8), while M is Marker; (b) Molecular Phylogenetic analysis by Maximum Likelihood method. Sample Ais BE 14 isolate and sample B is BE 8 isolate

Isolates BE 14 (sample A) is Bacillus subtils with a similarity of $100 \%$ of Bacillus subtilis ZJ2 (Accession KY121111.1), while isolate BE 8 is the similarity of $99 \%$ of Bacillus cereus Se05 (Accession JN700108.1).

\section{Characterizatio of cellulase enzyme activity}

Bacterial isolates was grown in medium CYPE broth (Bajaj et al., 2009) at pH 7, incubated at $30^{\circ} \mathrm{C}$ with a speed of $150 \mathrm{rpm}$ for 18 hours. Culture that has gained further centrifuged at $10,000 \mathrm{rpm}$ for $10 \mathrm{~min}$ at $4^{\circ} \mathrm{C}$. The resulting filtrate is then used to test the ability of cellulolytic (characterization of crude cellulase enzymes). The enzyme activity was measured using the substrate CMC or endoglucanase activity.

\section{Effect of $\mathrm{pH}$ and temperature on activity cellulase (endoglucanase)}

The optimum $\mathrm{pH}$ for enzyme activity was found $\mathrm{pH} 6$ and temperature optimal was found $60{ }^{\circ} \mathrm{C}$ 

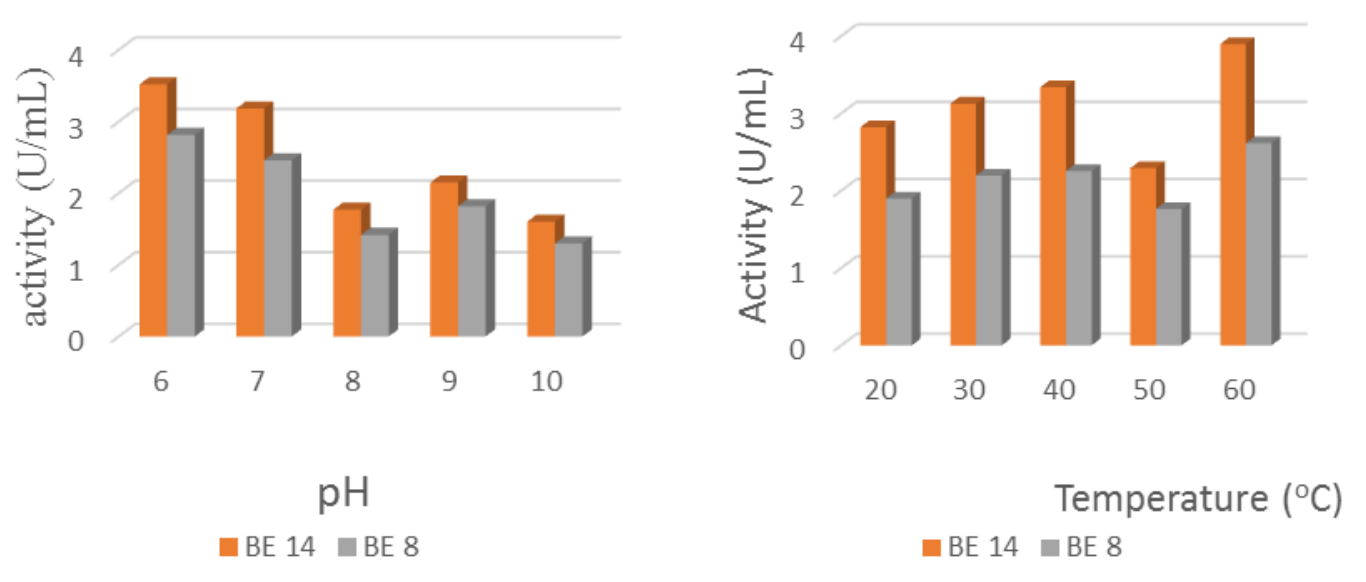

Figure 3. Effect of $\mathrm{pH}$ and temperature of endoglucanase production

Effect of substrate concentration and metal ions on activity cellulase

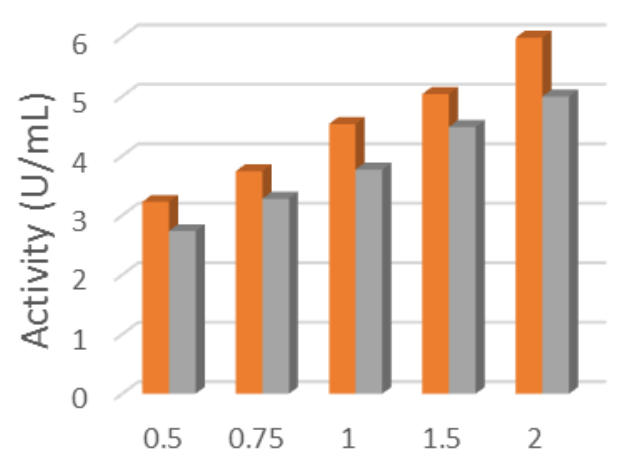

$[\mathrm{CMC}] \%$

- $\mathrm{BE} 14 \square \mathrm{BE} 8$

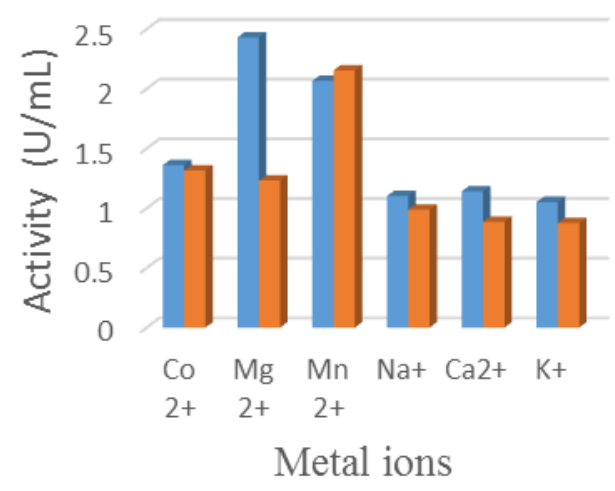

$\square \mathrm{BE} 14 \square \mathrm{BE} 8$

Figure 4. Effect of CMC concentration of endoglucanase production

The optimum substrate concentrastion for enzyme activity was found $2 \%$ CMC and metal ion optimal was found $\mathrm{Mg}^{2+}$ of isolate $\mathrm{BE} 14$, while $\mathrm{Mn}^{2+}$ of isolate $\mathrm{BE} 8$

\section{REFERENCES}

Miller G.L., 1959, Use of Dinitrosalicylic Acid Reagent for Determination Of Reducing Sugars, Analytical Chemistry, 31, pp 426-429.

Bajaj, B.K., Pangotra, H., Wani, M.A., Sharma, P. \& Sharma, A., 2009, Partial Purification and Characterization of a highly thermostable and $\mathrm{pH}$ Stable Endoglucanase from a newly Isolated Bacillus Strain M-9, Indian Journal of Chemical Technology, Vol.16, pp.382387 
Ardiansyah. 2010. SehatdenganMengkonsumsiBekatul.

Singh, A. K., A.K.Maharana, , H.Masih, Y.Kumar, \& S.K.Mishra, , 2012, Production, optimization and purification of bacterial cellulase by solid state bioprocessing of agro biomass, Research Journal of Pharmaceutical, Biological and Chemical Sciences, April June 2012, RJPBCS, Volume 3, Issue 2, Page No. 978

Nirmala, P. \&Sindhu, A., 2011, Production of Endoglucanase by Optimizing the Environmental Conditions of Bacillus circulanson Submerged Fermentation, International Journal Of Applied Engineering Research, Dindigul, Volume 2 No 2 2011, ISSN-0976-4259 